\title{
Evaluation of Antibacterial Activity of Bryopsis pennata and Chaetomorpha antennina against Multidrug Resistant Morganella morganii and Salmonella species Isolated from Healthy Individuals
}

\author{
Folashade Agbaje-Daniels ${ }^{1,2^{\star}}$, Agape Babalola ${ }^{1}$, Ifeoluwa Akintayo ${ }^{1}$, \\ Adeyemi Adeleye $^{2}$ and Denzil Beukes ${ }^{3}$ \\ ${ }^{1}$ Department of Biological Sciences, Crawford University, Igbesa, Ogun State, Nigeria. \\ ${ }^{2}$ Department of Microbiology, University of Lagos, Lagos, Nigeria. \\ ${ }^{3}$ Department of Pharmaceutical Chemistry, School of Pharmacy, University of Western Cape, Bellville, \\ Capetown, South Africa. \\ Authors' contributions \\ This work was carried out in collaboration between all authors. Author FAD designed the study, \\ performed the statistical analysis, wrote the protocol, wrote the first draft of the manuscript and \\ managed the literature searches. Authors $A B$ and IA managed the analyses of the study. Authors $A A$ \\ and $D B$ managed methodology and supervisory role. All authors read and approved the final
} manuscript.

Article Information

DOI: $10.9734 / J P R I / 2017 / 35924$

Editor(s):

(1) Krishna Gudikandula, Department of Microbiology, Kakatiya University, Warangal, India.

Reviewers:

(1) Essam Hussein Abdelshakour, Al-Azhar University, Egypt. (2) Mustapha Umar, Nigerian Institute of Leather and Science Technology, Nigeria. Complete Peer review History: http://www.sciencedomain.org/review-history/20797

Original Research Article

Received $2^{\text {nd }}$ August 2017

Accepted $24^{\text {th }}$ August 2017

Published $2^{\text {nd }}$ September 2017

\begin{abstract}
The problem of antibiotic resistance is fast becoming a pandemic which has necessitated the need for new drugs discovery. This study was carried out to screen two green algal species- Bryopsis pennata and Chaetomorpha anteninna for antibacterial activity against multidrug resistant pathogenic enteric organisms (Morganella morganii and Salmonella species) obtained from healthy individuals. Algal samples were obtained and processed. Crude extraction was carried out with
\end{abstract}

*Corresponding author: E-mail: sade.agbaje-daniels@crawforduniversity.edu.ng, teeshade@yahoo.com; 
dichloromethane/methanol (2:1) while the antibacterial screening was done by agar-well diffusion method. Results revealed that $M$. morganii was $3.37 \%$ of the total isolates recovered while Salmonella species was $6.74 \%$. Result also showed that $C$. antennina was active against all the strains of Salmonella species with inhibitory zones ranging from $10 \mathrm{~mm}$ to $17 \mathrm{~mm}$ and the M. morganii with inhibitory zone of $11 \mathrm{~mm}$ while $B$. pennata showed inhibitory activities against only S. pullorum and $S$. enterica subspecies diarizonae with inhibitory zones of $12 \mathrm{~mm}$ and $7 \mathrm{~mm}$ respectively as well as the $M$. morganii strain with $14 \mathrm{~mm}$. The antibacterial activities observed from these green algae showed that Bryopsis pennata and Chaetomorpha antennina from the West African coast are promising in the quest for new drugs with potentials against multidrug resistant strains of bacteria and therefore should be intensely researched into.

Keywords: Bryopsis peñata; Chaetomorpha antennina; Morganella morganii; Salmonella species.

\section{INTRODUCTION}

Human anatomical sites habour a variety of microorganisms both in health and disease state. Although many are regarded as commensals but could become pathogenic under certain conditions [1]. Diseases and disease agents that were once controlled by antibiotics are returning in new leagues resistant to these therapies [2]. Zafar et al. [3] revealed that microbial susceptibility to the commonly prescribed antibiotics had drastically decreased in the last decade. This resistance to antimicrobials has led to increased morbidity, mortality and high cost of health care [4]. The physical and chemical conditions in the marine environment had been attributed to the exhibition of a variety of molecules with unique structural features by almost every class of marine organism [5]. Reports had shown that an emerging source of new bio-actives might result from the many recent studies of microbial diversity in the marine environment [6]. The marine environment harbors bacteria with antagonistic traits and marine microorganisms are a potential source of novel antimicrobials [7]. Many of the secondary metabolites produced by marine organisms are halogenated, reflecting the availability of chloride and bromide ions in seawater [8].

Marine macroalgae are considered as an excellent source of bioactive compounds which has a broad range of biological activities including antibacterial [9,10], antifungal [11] antiviral [10], anti-tumor [12], antioxidant [13,14], and anti-inflammatories $[15,16]$. The production of antimicrobial activities was considered to be an indicator of the seaweeds to synthesize bioactive secondary metabolites $[17,18]$. Some algal substances have bacteriostatic and bactericidal activity, they have been extensively studied by several researchers [17,19,20,21]. The importance of macroalgae as a supply for new bioactive substances has been growing very rapidly in recent years according to Smit [22] and Mohamed et al. [23] due to their capacity to produce metabolites that exhibit various biological activities.

\section{MATERIALS AND METHODS}

\subsection{Sample Site}

Samples were collected from the paradise and Sakumono beaches in Accra, Ghana.

\subsubsection{Sample collection}

Species of fresh algae were collected by detaching them from rock surfaces at low tides. Other samples were collected using a knife to pull off from rocks at low tides to avoid heavy wave action in March 2014 between the hours of $9.00 \mathrm{am}$ and $1 \mathrm{pm}$. These samples were immediately kept under ice in an ice-box and transported to the laboratory where they were sorted out and thoroughly washed with fresh water. These samples were properly identified and authenticated by a marine Botanist in the University of Ghana. They were kept frozen until extraction period.

\subsubsection{Crude extraction}

The crude extract was obtained by Maceration of algal sample for 30 mins at $40^{\circ} \mathrm{C}$ according to Afolayan et al. [24]. A mass of $50 \mathrm{~g}$ of the sample was macerated in $300 \mathrm{ml}$ of Dichloromethane: methanol (2:1) and the temperature was raised to about $40^{\circ} \mathrm{C}$ for 30 mins. After 30 mins, the supernatant was filtered and the process repeated two more times. The supernatant was dried en vacuo using rotary evaporator (Buchi 200 , Germany) at $40^{\circ} \mathrm{C}$. Extract concentrate was kept frozen until needed. 


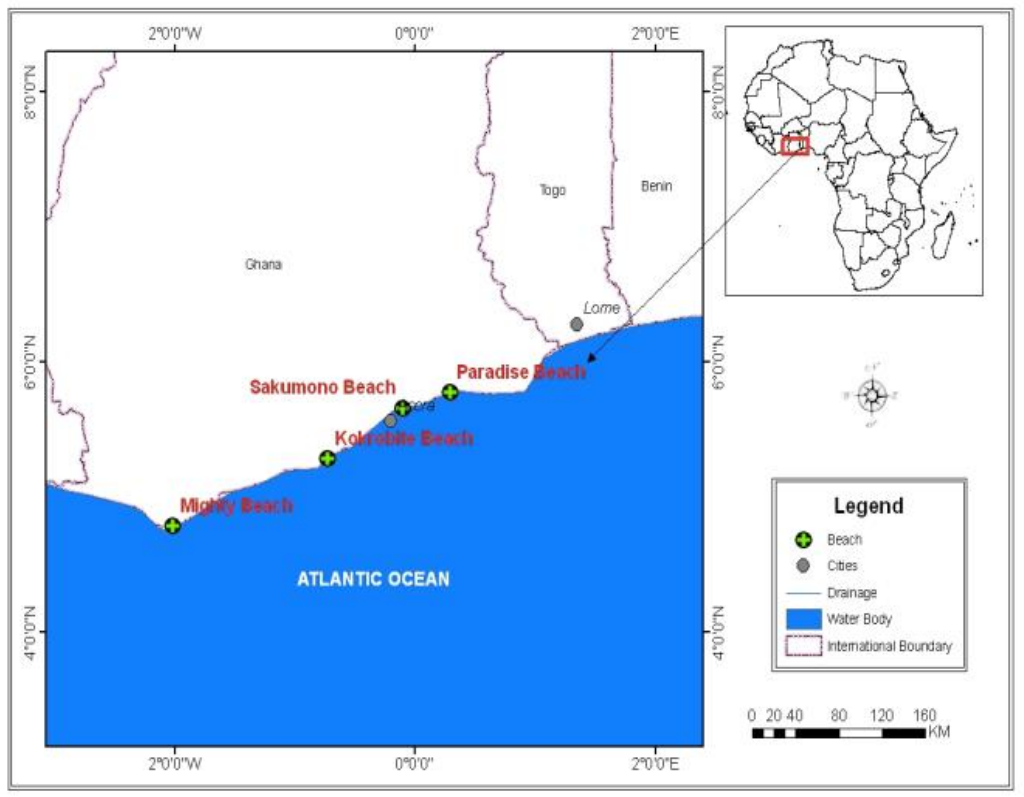

Map 1. Map showing the sampling sites

\subsubsection{Antibacterial screening of extract}

Fresh cultures of the different species of Salmonella species and Morganella morganii obtained from healthy individuals were obtained from the Microbiology laboratory, Crawford University, Igbesa, Ogun State. Using the agar well diffusion method to enumerate the antibiotic susceptibility pattern of the test bacteria. The test isolates were screened against the commonly prescribed antibiotics. Plates containing $20 \mathrm{ml}$ of Mueller-Hinton agar were seeded with cotton applicator dipped in bacterial suspension standardized with $0.5 \mathrm{McF}$ arland standard. Wells were bored with borer of $6 \mathrm{~mm}$ in diameter on the plates where $0.1 \mathrm{ml}$ i.e. $200 \mathrm{mg} / \mathrm{ml}$ of the extract were introduced into the wells, and was allowed to diffuse for some minutes before incubation at $37^{\circ} \mathrm{C}$ for 48 hours. The diameters of inhibition were measured. Antibiotic resistance profile was obtained by using the disc diffusion method of Bauer et al. [25] and NCCLS [26].

\section{RESULTS}

Result shows the sensitivity profile of Morganella morganii, Salmonella enterica subspecies diarizonae, Salmonella enterica subspecies houtenae and Salmonella pullorum.

Morganella morganii was resistance to all the antibiotics while some of the Salmonella species were resistance and some sensitive to the antibiotics. Table 1 shows the antibiotic resistance profile of test isolates.

The antibacterial screening of Bryopsis pennata against the isolates revealed that all tested isolates were inhibited except a strain of Salmonella enterica subspecies diarizonae and Salmonella enterica subspecies houtenae. The zone of inhibition was highest in M. morganii (14 $\mathrm{mm}$ ) and lowest in another strain of Salmonella enterica subspecies diarizonae $(7 \mathrm{~mm})$. This is shown below in Table 2 .

The result for Chaetomorpha antennina antimicrobial screening revealed that all test isolated were inhibited by the alga with zones of inhibition ranging from $10 \mathrm{~mm}$ (in Salmonella enterica subspecies houtenae, Salmonella enterica subspecies diarizonae and S. pullorum) to $17 \mathrm{~mm}$ (Salmonella enterica subspecies diarizonae). (Table 3).

\section{DISCUSSION}

The search for new antimicrobial agents has been on the rise due to the resistance of some pathogenic microorganisms to commonly prescribed antimicrobial drugs. High antimicrobial resistance had been previously reported amongst enteric organisms. The seaweeds are a promising source of natural products because they produce varieties of bioactive compounds [27]. 
Table 1. Antibiotic resistance profile of test isolates

\begin{tabular}{|c|c|c|}
\hline & OFL & AUG \\
\hline $\begin{array}{l}\text { Salmonella enterica } \\
\text { subspecies diarizonae }\end{array}$ & $S$ & $\mathrm{R}$ \\
\hline $\begin{array}{l}\text { Salmonella enterica } \\
\text { subspecies diarizonae }\end{array}$ & $S$ & $\mathrm{R}$ \\
\hline Salmonella pullorum & $S$ & $\mathrm{R}$ \\
\hline $\begin{array}{l}\text { Salmonella enterica } \\
\text { subspecies houtenae }\end{array}$ & $S$ & $\mathrm{R}$ \\
\hline Morganella morganii & $\mathrm{R}$ & $\mathrm{R}$ \\
\hline \multirow{2}{*}{\multicolumn{3}{|c|}{$\begin{array}{l}\text { Key: OFL- Ofloxacin, AUG- Augumetin, NIT-Nitrc } \\
\text { Cefuroxime, GEN- Gentamicin, CXM-Ceftriaxone, } \\
\text { Table 2. The antibacterial screening of } \\
\text { Bryopsis pennata against Salmonella species } \\
\text { and Morganella morganii at } 200 \mathrm{\mu g} / \mathrm{ml}\end{array}$}} \\
\hline & & \\
\hline Test Bacteria & \multicolumn{2}{|c|}{$\begin{array}{l}\text { Zone of } \\
\text { inhibition }(\mathrm{mm})\end{array}$} \\
\hline $\begin{array}{l}\text { Salmonella enterica } \\
\text { subspecies houtenae }\end{array}$ & \multicolumn{2}{|c|}{0.00 (N.A) } \\
\hline Salmonella pullorum & \multicolumn{2}{|c|}{12.00} \\
\hline $\begin{array}{l}\text { Salmonella enterica } \\
\text { subspecies diarizonae }\end{array}$ & \multicolumn{2}{|l|}{7.00} \\
\hline $\begin{array}{l}\text { Salmonella enterica } \\
\text { subspecies diarizonae }\end{array}$ & \multicolumn{2}{|c|}{0.00 (N.A) } \\
\hline Morganella morganii & \multicolumn{2}{|c|}{14.00} \\
\hline
\end{tabular}

Table 3. The antibacterial screening of Chaetomorpha antennina against Salmonella species and Morganella morganii at $200 \mu \mathrm{g} /$

\begin{tabular}{ll}
\hline Test bacteria & $\begin{array}{l}\text { Zone of } \\
\text { inhibition } \mathbf{( m m})\end{array}$ \\
\hline $\begin{array}{l}\text { Salmonella enterica } \\
\text { subspecies houtenae }\end{array}$ & 10.00 \\
$\begin{array}{l}\text { Salmonella pullorum } \\
\text { Salmonella enterica }\end{array}$ & 10.00 \\
subspecies diarizonae & 17.00 \\
$\begin{array}{l}\text { Salmonella enterica } \\
\text { subspecies diarizonae }\end{array}$ & 10.00 \\
Morganella morganii & 11.00 \\
\hline
\end{tabular}

From this study, dichloromethane extract of Chaetomorpha antennina was active against different species of Salmonella (Salmonella pullorum, Salmonella enteric subspecies diarizonae, and Salmonella enetrica subspecies houtenae) which gave a zone of inhibition ranging from $10.00 \mathrm{~mm}-17.00 \mathrm{~mm}$, previous reports revealed that Dichloromethane (DCM) and methanolic crude extracts of some algae had biological activities [24], and it has also been

\begin{tabular}{llllll} 
NIT & CPR & CAZ & CRX & GEN & CXM \\
$\mathrm{S}$ & $\mathrm{S}$ & $\mathrm{R}$ & $\mathrm{R}$ & $\mathrm{S}$ & $\mathrm{R}$ \\
$\mathrm{S}$ & $\mathrm{R}$ & $\mathrm{R}$ & $\mathrm{R}$ & $\mathrm{S}$ & $\mathrm{R}$ \\
$\mathrm{S}$ & $\mathrm{S}$ & $\mathrm{R}$ & $\mathrm{R}$ & $\mathrm{R}$ & $\mathrm{R}$ \\
$\mathrm{R}$ & $\mathrm{S}$ & $\mathrm{R}$ & $\mathrm{R}$ & $\mathrm{S}$ & $\mathrm{R}$ \\
$\mathrm{R}$ & $\mathrm{R}$ & $\mathrm{R}$ & $\mathrm{R}$ & $\mathrm{R}$ & $\mathrm{R}$ \\
\hline
\end{tabular}

furantoin, CPR-Ciprofloxacin, CAZ-Ceftazidime, CRXabove)

reported from phytochemical analysis of Chaetomorpha antennina crude extract that it contains glycosides, tannin, terpenoids and phenolics [28]. The inhibitory activities observed in this study would be credited to the presence of these biologically active metabolites. Terpenoids and phenolics had been previously reported as good antimicrobials [29] so also are glycosides and tannins [30].

This study revealed the inhibitory activity of $C$. antennina against $M$. morganii. The inhibitory activity of a green alga (Caulerpa cupressoides) against $M$. morganii had been previously reported [31]. The virulence of $M$. morganii could be attributed to the possession of resistance plasmid which had previously been reported by Cunha [32]. This agent has been reportedly implicated in nosocomial infections, sepsis and some other infections [33]. The involvement of this bacterium in such infections poses a health threat because of its multiple resistance to antimicrobial drugs as previously been reported and observed in this study. Also, C. antennina extract showed inhibitory activities against Salmonella pullorum, Salmonella enterica subspecies diarizonae, Salmonella enterica subspecies houtenae and Morganella morganii. Salmonella pullorum infection affects birds and poultry products and this could be easily transmitted to man through consumption of such food.

The antibacterial screening of $B$. pennata against the species of Morganella and Salmonella in this study revealed the inhibitory activities of this alga against the bacteria. The $B$. pennata crude extract was active against $M$. morganii and some of the strains of Salmonella species tested. Previous reports revealed the isolation of fatty acid and sterols [34] as well as depsipeptides [35] from this alga. 
Fatty acids and sterols have previously been reported as good antimicrobial compounds. Depsipeptides' pharmacological activities had also been previously documented [36]. The inhibitory activities observed against these bacterial species may thus be attributed to these compounds. The crude extracts of the algae in this study inhibited multiple drug resistant enteric bacteria as observed in this study. This informs that if properly researched into, pure compounds from these algae could be really promising in the quest for new antimicrobial drugs against multiple-drug resistant pathogens.

\section{CONCLUSION}

These results provide good evidence that antimicrobial chemical defenses are wide spread among marine algae, they have shown that algae are promising organisms to furnish novel biochemically active compounds in pharmaceutical industry. Moreover, the activity profile of the algal extract suggests that antimicrobial secondary metabolites can be pathogen-selective or broad-spectrum effective. This result also buttresses the fact that marine algae from West African coasts if well explored may bring great therapeutic intervention against the problem of drug-resistance.

\section{CONSENT}

It is not applicable.

\section{ETHICAL APPROVAL}

It is not applicable.

\section{COMPETING INTERESTS}

Authors have declared that no competing interests exist.

\section{REFERENCES}

1. Anderson BE. The netter collection of medical illustrations - integumentary system. $2^{\text {nd }}$ Edition. Elsevier Saunders, 1600John F. Kennedy Boulivard, Stc 1800, Philadelphia, PA. 2012;4r:619183-2899.

2. Levy SB, Marshall B. Antibacterial resistance worldwide; causes, challenges and responses. Nature Medicine Sup. 2004;S122-S130.
3. Zafar S, Baqir S, Naqvi S, Ali M, Abbass T, Qazi F, Sheikh R. Resistance pattern in clinical isolates of Eschericia coli against four groups of antibiotics. Int. Res $J$ Pharm. App Sci. 2014;4(1):100-106.

4. Levy SB. The future of antibiotics: Facing antibiotic resistance. Clin. Microbiol. Infect. 2000;6(3):101-106.

5. Anake K. and Pichan S. Drugs and Cosmetics from the Sea. Marine Drugs. 2004;2(2):73-82.

6. Martinez-Garcia $M$, Diaz-Valdes $M$, Wanner G, Ramos-Espla A, Anton J. Microbial community associated with the colonial ascidian Cystodytes dellechiajei. Environmental Microbiology. 2007;9:521534.

7. Zhang L, An R, Wang J, Sun N, Zhang S, $\mathrm{Hu} J$, Kuai J. Exploring novel bioactive compounds from marine microbes. Current Opinion in Microbiology. 2005;8:276-281.

8. Cabrita MT, Vale C, Router AP. Halogenated compounds from marine algae. Marine Drugs. 2010;8:2301-2317.

9. Singh A. and Chaudhary B. Preliminary phycochemical analysis and in vitro antibacterial screening of Pithophora oedogonia (Mont.) Wittrock: A freshwater green alga forming mats in the water bodies. Journal of Algal Biomass Utilization 2010;1:33-41.

10. Bouhlal $\mathrm{R}$, Riadi $\mathrm{H}$, Bourgougnon $\mathrm{N}$. Antiviral activity of the extracts of rhodophyceae from Morocco. African Journal of Biotechnology. 2010;9:79687975.

11. De Felício $R$, Dealbuquerque $S$, Young MCM, Yokoya NS, Debonsi HM. Trypanocidal, leishmanicidal and antifungal potential from marine red alga Bostrychiatenella J. Agardh (Rhodomelaceae, Ceramiales). Journal of Pharmaceutical and Biomedical Analysis. 2010;52:763-769.

12. Kim SK, Karadeniz F. Anti-HIV activity of extracts and compounds from marine Algae. Advance Food Nutrition Research. 2011;64:255-265.

13. Kudaa T, Tsunekawaa M, Gotoa H, Arakib Y. Antioxidant properties of four edible algae harvested in the Noto Peninsula, Japan. J of Food Comp. and Ana. 2005;18: 625-633.

14. Devi GK, Manivannan K, Thirumaran GM, Rajathi FAA, Anantharaman P. In vitro antioxidant activities of selected seaweeds from southeast coast of India. Asian Pacific J. Trop. Med. 2011;205-211. 
15. Tuney I, Cadirci BH, Unal D, Sukatar A. Antimicrobial activities of the extracts of marine algae from the coast of Urla (Izmir, Turkey). Turkish Journal of Biology. 2006; 30:171-175.

16. Patra JK, Rath SK, Jena K, Rathod VK, Thatoi $H$. Evaluation of antioxidant and antimicrobial activity of seaweed (Sargassum spp.). Extract: A study on inhibition of glutathione-S-transferase activity. Turkish Journal of Biology. 2008; 32:119-125.

17. Gonzalez AD, Basilio A, Cabello J, Gorrochategul I, Suay F, Vicente E, Portillo JDM, Rio RGG, Pelaez F. Screening of antimicrobial activities in red, green and brown macroalgae from Gran canaria (Canary Islands, Spain). Int. Microbial. 2001;4(3):35-40.

18. Srivastava N, Saurav K, Mohanasrinivasan V, Kannabiran K, Singh M. Antibacterial potential of macroalgae collected from the Madappam Coast, India. British Journal of Pharmacology and Toxicology. 2010;1(2): 72-76.

19. Ghosh P, Adhikari U, Ghosal PK, Pujol CA, Carlucci MJ, Damonte EB, Ray B. In vitro anti-herpetic activity of sulfated polysaccharide fractions from Caulerpa racemosa. Phytochemistry. 2004;65:31513157.

20. Salvador N, Gómez GA, Lavelli L, Ribera MA. Antimicrobial activity of Iberian macroalgae. Sci. Mar. 2007; 71:101-113.

21. Taskin E, Ozturk M, Taskin E, Kurt O. Antibacterial activities of some marine algae from the Aegean Sea (Turkey). African Journal of Biotechnology. 2007;6: 2746-2751.

22. Smit AJ. Medicinal and pharmaceutical uses of seaweed natural products. A review. J. Appl. Phycol. 2004;16:245-262.

23. Mohamed AD, Abou-Dobara MI. Antibacterial activity of some marine algal extracts against most nosocomial bacterial infections. Egypt. J. Exp. Biol. (Bot.). 2012; 9(2):281-286.

24. Afolayan AF, Bolton JJ, Lategan CA, Smith PJ, Beukes DR. Fucoxanthin, tetraprenylatedtoluquinone and toluhydroquinone metabolites from Sargassum heterophyllum inhibit the in vitro growth of the malaria parasite Plasmodium falciparum. Z Naturforsch 2008;63:848-852.
25. Bauer AW, Kirby MM, Sherris JC. and Truck M. Antibiotic susceptibility testing by a standardized single disk method. Am J Clinpathol. 1966;45:493-6.

26. National Committee for Clinical Laboratory Standards Methods for Dilution Antimicrobial Susceptibility (NCCLS). Tests for bacteria that grow aerobically; approved standard M27-A9, Wayne. Clinical and Laboratory Standards Institute, Wayne. Clinique. 2012;32(9):1228.

27. Chauhan J, Kasture A. Review article antimicrobial compounds of marine algae from indian coast. Int. J. Curr. Microbiol. App. Sci. 2014;3(7):526-532.

28. Premalatha $M$, Dhasarathan $P$. and Theriappan P. Phytochemical characterization and antimicrobial efficiency of seaweed sample Ulva fasciata and Chaetomorpha antennina. Int. J. Pharm Biol Sci. 2011;2(1).

ISSN: 0975-6299.

29. Souza AB, Martins CHG, Souza MGM, Furtado NAJ, Heleno VCG, de Sousa JPB, Rocha EMP, Bastos JK, Cunha WR, Veneziani RCS, Ambrósio SR. Antimicrobial activity of terpenoids from Copaifera langsdorffii Desf. against cariogenic bacteria. Phytotherapy Research. 2011;25(2):215-220.

DOI: $10.1002 / p t r .3244$

30. Doss A, Mubarack HM, Dhanabalan R. Antibacterial activity of tannins from the leaves of Solanum trilobatum Linn. Indian J. Sci. Technol. 2009;2:41-43.

31. Lima-Filho JVM, Carvalho AFFU, Freitas SM, Melo VMM. Antibacterial activity of extracts of six macroalgae from the Northeastern Brazilian Coast. Brazilian Journal of Microbiology. 2002;33:311-313.

32. Cunha MD. Proteeae infections. Merck Manual. 2012;12.08.12.

33. Singla N, Neelam K, Neelam G, Jagdish C. Morganella morganii could be an important intensive care unit pathogen. Indian Journal of Critical Care Medicine. 2010; 14(3):154-155.

34. Li X, Fan X, Han L, Lou Q. Fatty acids of some algae from the Bohai Sea. Phytochemistry. 2002;59:157-161.

35. Dmitrenok A, Iwashitta T, Nakajima T, Sakamoto B, Namikoshi M, Nagai H. New cyclic depsipeptides from green alga spp; application of a carboxypeptidase hydrolysis reaction to the structure 
Agbaje-Daniels et al.; JPRI, 18(4): 1-7, 2017; Article no.JPRI .35924

determination. Tetrahedron. 2006;62: pubmed.gov; 2007.

1301-1308.

36. National Institute of Health. In

Available:www.ncbi.gov/pubmed/18604953

(c) 2017 Agbaje-Daniels et al.; This is an Open Access article distributed under the terms of the Creative Commons Attribution License (http://creativecommons.org/licenses/by/4.0), which permits unrestricted use, distribution, and reproduction in any medium, provided the original work is properly cited.

Peer-review history:

The peer review history for this paper can be accessed here: http://sciencedomain.org/review-history/20797 